\title{
Hubungan Antara Umur, Gravida, Dan Status Bekerja Terhadap Resiko Kurang Energi Kronis (KEK) Dan Anemia Pada Ibu Hamil
}

\section{Relationship Between Age, Gravida, And Working Status Against Chronic Energy Deficiency And Anemia In Pregnant Women}

\author{
Zahidatul Rizkah*1, Trias Mahmudiono²
}

\begin{abstract}
ABSTRAK
Latar Belakang: Proporsi ibu hamil dengan KEK di Indonesia berdasarkan Riset Kesehatan Dasar mengalami peningkatan yaitu pada tahun 2010 sebesar 33,5\% meningkat menjadi 38,5\% pada tahun 2013.

Tujuan: Tujuan dari penelitian ini adalah untuk mengetahui pengaruh umur, gravida, dan status bekerja terhadap kejadian KEK dan Anemia pada ibu hamil.

Metode: Penelitian cross-sectional ini melibatkan 153 ibu hamil yang periksa selama bulan JanuariDesember 2014 sebagai sampel. Sampel ini dipilih secara acak dengan menggunakan teknik simple random sampling. Pengaruh antar variabel dianalisis menggunakan uji Logistic Regression $(\alpha=0,05)$. Hasil: Hasil penelitian menunjukkan bahwa ibu yang tidak bekerja memiliki kemungkinan 0,824 kali untuk mengalami KEK dibandingkan dengan ibu yang bekerja, ibu multigravida memiliki kemungkinan 1,021 kali untuk mengalami KEK dibandingkan dengan ibu primigravida, dan 3,200 kali untuk mengalami KEK dibandingkan dengan ibu primigravida, . Ibu hamil yang berumur $<20$ tahun memiliki resiko mengalami Anemia 2,250 kali dibandingkan dengan umur 20-35 tahun, dan usia > 35 tahun memiliki resiko mengalami Anemia 5,885 kali lebih besar dibandingkan dengan usia 20-35 tahun. Ibu yang tidak bekerja memiliki resiko mengalami Anemia 1,990 lebih besar dibandingkan dengan ibu hamil yang bekerja.

Kesimpulan: Kesimpulan dari penelitian ini adalah terdapat pengaruh status bekerja, primigravida terhadap kejadian KEK, dan terdapat pengaruh umur, status bekerja, dan gravida terhadap kejadian Anemia pada ibu hamil. Saran untuk ibu hamil adalah untuk melakukan konseling kepada petugas kesehatan secara teratur dan memenuhi kebutuhan nutrisinya selama hamil sesuai saran petugas kesehatan untuk mencegah terjadinya KEK dan anemia pada masa kehamilan.
\end{abstract}

Kata kunci: Umur, Gravida, Status Bekerja, KEK, Anemia 


\begin{abstract}
Background: Chronic Energy Deficiency, and Anemia in pregnancy have become two the indirect and major causes of maternal and infant mortality cases in Indonesia.

Objectives: The purpose of this study was to determine the effect of age, gestational age, gravida on Chronic Energy Deficiency occurrence and anemia.

Methods: . The purpose of this study was to determine the effect of age, gravida, and work status on Chronic Energy Deficiency occurrence and Anemia.

Results: The results showed that unemployed mothers had a probability of 0.824 times for Chronic Energy Deficiency compared with working mothers, multigravidal mothers had a probability of 1.021 times for Chronic Energy Deficiency compared with primigravida mothers, and 3,200 times for Chronic Energy Deficiency compared with primigravida mothers. Pregnant women $<20$ years of age have an anemia risk of 2.250 times compared with age 20-35 years, and age $>35$ years have anemia risk 5.885 times greater than the age of 20-35 years. Unhealthy mothers and mothers who have risk of Anemia 1.990 greater than pregnant women who work.

Conclusion: The conclusion of this research is that there is influence of work status, primigravida to Chronic Energy Deficiency occurrence, and there is influence of age, working status, and gravida on occurrence Anemia in pregnant mother. Advice for pregnant women is to conduct counseling to health workers on a regular basis and meet the nutritional needs during pregnancy according to the advice of health workers to prevent the occurrence of Chronic Energy Deficiency and anemia during pregnancy.
\end{abstract}

Keywords: Age, Gravida, Working Status, Chronic Energy Deficiency, Anemia

\footnotetext{
*Koresponden:

zahidatul32@gmail.com

${ }^{1}$ Departemen Keselamatan dan Kesehatan Kerja

${ }^{2}$ Departemen Gizi Kesehatan,

Fakultas Kesehatan Masyarakat-Universitas Airlangga
} 


\section{PENDAHULUAN}

Proporsi ibu hamil dengan KEK di Indonesia berdasarkan Riset Kesehatan Dasar mengalami peningkatan yaitu pada tahun 2010 sebesar 33,5\% meningkat menjadi 38,5\% pada tahun 2013 Terdapat $37,1 \%$ ibu hamil yang mengalami Anemia, yaitu ibu hamil dengan kadar $\mathrm{Hb}$ kurang dari 11,0 gram/dl, dengan proporsi yang hampir sama antara kawasan di pedesaan $(37,8 \%)$ dan di kawasan perkotaan $(36,4 \%)$ pada tahun $2013^{1}$.

KEK pada ibu hamil dapat menyebabkan resiko dan komplikasi pada ibu antara lain adalah : berat badan ibu tidak bertambah secara normal, Anemia, pendarahan, dan terkena penyakit infeksi. Sedangkan Pengaruh KEK terhadap proses persalinan dapat mengakibatkan persalinan sebelum waktunya (prematur), persalinan sulit dan lama, pendarahan setelah persalinan, serta persalinan dengan operasi cenderung meningkat ${ }^{2}$.

Selain itu, KEK ibu hamil juga dapat mempengaruhi proses pertumbuhan janin dan dapat menimbulkan keguguran, abortus, Anemia pada bayi, asfiksia intrapartum (mati dalam kandungan), lahir dengan berat badan lahir rendah (BBLR), bayi lahir mati, kematian neonatal, cacat bawaan ${ }^{3}$. Sedangkan Haemoglobin $(\mathrm{Hb})$ merupakan parameter yang digunakan untuk mengetahui prevalensi Anemia. Dampak yang ditimbulkan dari ibu hamil yang mengalami Anemia adalah meningkatnya resiko melahirkan bayi dengan $B B L R^{4}$.

Anemia pada kehamilan ini ditandai karena terjadi penurunan kadar $\mathrm{Hb}$ pada trimester II karena pengenceran darah (haemodilusi) sehingga terjadi Anemia fisiologis dan bila kadar $\mathrm{Hb}<11$ gr\% terjadi Anemia patologis 5 . Anemia dapat mengakibatkan terjadinya perdarahan postpartum, abortus, partus lama, infeksi, dan berat badan lahir bayi rendah (BBLR) ${ }^{3}$.

Anemia dapat dipengaruhi oleh beberapa faktor yaitu umur, pendidikan, status ekonomi, paritas, jarak kelahiran, kebiasaan, dan KEK. Sedangkan untuk ibu hamil dengan KEK (Kekurangan Energi Kronik) dapat disebabkan karena ketidakseimbangan asupan zat gizi (energy dan protein), sehingga zat gizi yang dibutuhkan oleh tubuh tidak tercukupi ${ }^{6}$.

Berdasarkan penelusuran penelitian sebelumnya di Puskesmas Wonoayu Kabupaten Sidoarjo didapatkan hasil bahwa dari 53 ibu hamil, sebanyak 21 ibu hamil (39,6\%) dalam kategori KEK dan 32 ibu hamil $(60,4 \%)$ tidak KEK ${ }^{7}$. Dan berdasarkan penelusuran penelitian sebelumnya yang dilakukan di Kabupaten Sidoarjo didapatkan hasil bahwa kejadian Anemia masih tinggi mencapai $90 \%$ dari sampel sebanyak 20 ibu hamil ${ }^{7}$.

Hal ini sungguh menghawatirkan karena ibu hamil tersebut telah mendapatkan tablet penambah darah dan meminumnya secara teratur ${ }^{8}$. KEK dan Anemia selama hamil mempunyai dampak yang serius untuk kesehatannya dan janinnya, sehingga kondisi KEK dan Anemia pada ibu hamil sebaiknya segera di tindak lanjuti. Berdasarkan uraian diatas maka, penelitian ini bertujuan untuk mengetahui pengaruh umur, usia kehamilan, gravida terhadap kejadian KEK dan Anemia.

\section{METODE}

Jenis penelitian ini adalah observasional analitik untuk menganalisis pengaruh umur, gravida, dan status bekerja terhadap kejadian KEK dan Anemia. Metode pengukuran dengan cara mengukur LILA dan mengukur kadar $\mathrm{Hb}$ dengan metode sahli ( pembentukan asam hematin) Ibu hamil. Kriteria KEK yaitu $<23,5 \mathrm{~cm}$, sedangkan untuk anemia pada ibu hamil yaitu Trimester I kurang dari11,00gr/dl, Trimester II kurang dari 10,50gr/dl, dan Trimester III kurang dari 11,0gr/dl. Desain penelitian ini adalah cross sectional karena dilakukan pada sekali waktu yaitu pada Bulan Januari 2017 dan data yang diambil merupakan data bulan Januari sampai Desember Tahun 2014 di Bidan Praktek Mandiri (BPM) Nunik Kustantina Tulangan. Data yang diambil adalah umur, pendidikan, status bekerja, usia kehamilan, dan gravida ibu hamil.

Penentuan besar sampel
menggunakan rumus dari Slovin dan
didapatkan besar sample adalah 153 ibu


hamil. Teknik sampling menggunakan simple random sampling dengan menggunakan tehnik lotre/ undian. Data yang diperoleh

\section{HASIL DAN PEMBAHASAN}

Berdasarkan Pada Tabel 1 dapat diketahui bahwa ibu hamil yang mengalami KEK paling banyak (83,3\%) adalah usia $20-35$ tahun, sama halnya ibu hamil yang tidak mengalami KEK paling banyak $(83,8 \%)$ adalah usia 20-35 tahun. Untuk pendidikan, paling banyak $(83,3 \%)$ yang mengalami KEK adalah ibu hamil dengan pendidikan menengah, sama halnya ibu hamil yang tidak mengalami KEK paling banyak $(82,1 \%)$ adalah ibu hamil dengan pendidikan menengah. Diketahui pula bahwa ibu hamil yang mengalami KEK paling banyak $(61,1 \%)$ adalah ibu hamil yang bekerja, kemudian dilakukan analisis menggunakan uji statistic logistic regression.

sama halnya dengan yang tidak KEK paling banyak $(56,4 \%)$ adalah ibu hamil yang tidak bekerja.

Gravida ibu hamil yang mengalami KEK paling banyak $(77,8 \%)$ adalah ibu primigravida, sedangkan ibu hamil yang tidak mengalami KEK paling banyak $(53,0 \%)$ adalah ibu multigravida. Sedangkan untuk usia kehamilan, ibu hamil yang mengalami KEK paling banyak $(55,6 \%)$ adalah ibu hamil pada trimester I, sama halnya dengan ibu hamil yang tidak mengalami KEK paling banyak $(58,1 \%)$ adalah ibu hamil trimester I. Hal ini terjadi karena saat pengambilan sampel didapatkan sampel sebagian besar adalah ibu hamil TM 1.

Tabel 1. Tabulasi silang kejadian KEK dengan umur, pendidikan, usia kehamilan, dan status bekerja Ibu Hamil

\begin{tabular}{|c|c|c|c|c|}
\hline \multirow{3}{*}{ Karakteristik } & \multicolumn{4}{|c|}{ Ukuran LILA } \\
\hline & \multicolumn{2}{|c|}{ KEK } & \multicolumn{2}{|c|}{ Tidak KEK } \\
\hline & $\mathbf{N}$ & $\%$ & $\mathbf{N}$ & $\%$ \\
\hline \multicolumn{5}{|l|}{ Umur } \\
\hline$<20$ th & 3 & 8,3 & 2 & 1,7 \\
\hline $20-35$ th & 30 & 83,3 & 98 & 83,8 \\
\hline$>35$ th & 3 & 8,3 & 17 & 14,5 \\
\hline \multicolumn{5}{|l|}{ Pendidikan } \\
\hline Dasar & 1 & 2,8 & 6 & 5,1 \\
\hline Menengah & 30 & 83,3 & 96 & 82,1 \\
\hline Tinggi & 5 & 13,9 & 15 & 12,8 \\
\hline \multicolumn{5}{|l|}{ Usia kehamilan } \\
\hline TM I & 20 & 55,6 & 68 & 58,1 \\
\hline TM II & 10 & 27,8 & 22 & 18,8 \\
\hline TM III & 6 & 16,7 & 27 & 23,1 \\
\hline \multicolumn{5}{|l|}{ Status bekerja } \\
\hline Bekerja & 22 & 61,1 & 66 & 56,4 \\
\hline Tidak bekerja & 14 & 38,9 & 51 & 43,6 \\
\hline
\end{tabular}


Tabel 2. Tabulasi silang kejadian Anemia dengan umur, pendidikan, status bekerja, gravida, dan usia kehamilan

\begin{tabular}{|c|c|c|c|c|}
\hline \multirow{3}{*}{ Karakteristik } & \multicolumn{4}{|c|}{ Kadar Hb } \\
\hline & \multicolumn{2}{|c|}{ Anemia } & \multicolumn{2}{|c|}{ Tidak Anemia } \\
\hline & $\mathbf{n}$ & $\%$ & $\mathbf{N}$ & $\%$ \\
\hline \multicolumn{5}{|l|}{ Umur } \\
\hline$<20$ tahun & 2 & 5,0 & 3 & 2,7 \\
\hline $20-35$ tahun & 26 & 65,0 & 102 & 90,3 \\
\hline$>35$ tahun & 12 & 30,0 & 8 & 7,1 \\
\hline \multicolumn{5}{|l|}{ Pendidikan } \\
\hline Dasar & 1 & 2,5 & 6 & 5,3 \\
\hline Menengah & 34 & 85,0 & 92 & 81,4 \\
\hline Tinggi & 5 & 12,5 & 15 & 13,3 \\
\hline \multicolumn{5}{|l|}{ Status bekerja } \\
\hline Bekerja & 18 & 45,0 & 70 & 61,9 \\
\hline Tidak bekerja & 22 & 55,0 & 43 & 38,1 \\
\hline \multicolumn{5}{|l|}{ Gravida } \\
\hline Primigravida & 17 & 42,5 & 62 & 54,9 \\
\hline Multigravida & 19 & 47,5 & 49 & 43,4 \\
\hline $\begin{array}{l}\text { Grandemulti } \\
\text {-gravida }\end{array}$ & 4 & 10,0 & 2 & 1,8 \\
\hline
\end{tabular}

Berdasarkan Pada Tabel 2 disajikan tabulasi silang antara Anemia dengan umur ibu hamil, pendidikan, status bekerja, gravida, dan usia kehamilan. Dapat diketahui bahwa ibu hamil yang mengalami Anemia paling banyak (65\%) adalah usia 20-35 tahun, sama halnya ibu hamil yang tidak mengalami Anemia paling banyak $(83,8 \%)$ adalah usia 20 35 tahun. Untuk pendidikan, paling banyak ( 85 $\%)$ yang mengalami Anemia adalah ibu hamil dengan pendidikan menengah, sama halnya ibu hamil yang tidak mengalami Anemia paling banyak $(81,4 \%)$ adalah ibu hamil dengan pendidikan menengah. Diketahui pula bahwa ibu hamil yang mengalami Anemia paling banyak (55\%) adalah ibu hamil yang tidak bekerja, sedangkan yang tidak mengalami Anemia paling banyak $(61,9 \%)$ adalah ibu hamil yang bekerja.

Gravida ibu hamil yang mengalami Anemia paling banyak (47,5\%) adalah ibu multigravida, sedangkan ibu hamil yang tidak mengalami Anemia paling banyak (54,9\%) adalah ibu primigravida. Dari tabel 3 dapat diketahui bahwa ibu yang tidak bekerja memiliki kemungkinan 0,824 kali untuk mengalami KEK dibandingkan dengan ibu yang bekerja. Hal ini disebabkan karena ibu rumah tangga yang tidak bekerja tidak memerlukan banyak asupan nutrisi dibandingkan dengan ibu yang bekerja. Lamanya waktu bekerja serta peran ganda ibu akan meningkatkan kebutuhan nutrisi dalam masa kehamilan sehingga berakibat pada suatu kerentanan terhadap masalah malnutrisi terutama selama masa kehamilan ${ }^{9}$.

Selain itu, diketahui pula bahwa ibu primigravida memiliki pegaruh yang signifikan terhadap kejadian KEK. Dari faktor gravida diketahui bahwa ibu multigravida memiliki kemungkinan 1,021 kali untuk mengalami KEK dibandingkan dengan ibu primigravida, kemudian ibu grandemultigravida juga memiliki kemungkinan 3,200 kali lebih besar untuk mengalami KEK dibandingkan dengan ibu primigravida. Hal ini menunjukkan semakin sering ibu mengalami kehamilan maka semakin besar kemungkinan mengalami KEK. 
Tabel 3. Pengujian Signifikansi Parameter Model Regresi Logistik Multivariat untuk kejadian KEK

\begin{tabular}{lccc}
\hline \multicolumn{1}{c}{ Variabel } & OR & 95\% & Sig \\
\hline Umur & & & \\
$\quad$ 20-35 tahun & Ref & & 0,150 \\
$<20$ tahun & 0,118 & $0,013-1,050$ & 0,053 \\
$\quad>35$ tahun & 0,576 & $0,158-2,102$ & 0,404 \\
\hline $\begin{array}{l}\text { Pendidikan } \\
\quad \text { Tinggi }\end{array}$ & Ref & & 0,839 \\
$\quad$ Menengah & 2,000 & $0,191-20,898$ & 0,563 \\
$\quad$ Dasar & 1,067 & $0,212-3,179$ & 0,903 \\
\hline Status Bekerja & & & \\
$\quad$ Bekerja & Ref & & 0,000 \\
$\quad$ Tidak Bekerja & 0,824 & $0,384-1,767$ & 0,618 \\
\hline Gravida & & & 0,023 \\
$\quad$ Primigravida & Ref & & 0,982 \\
$\quad$ Multigravida & 1,021 & $0,175-5,971$ & 0,211 \\
$\quad$ Grandemultigravida & 3,200 & $0,517-19,820$ & \\
\hline
\end{tabular}

Tabel 4. Hasil Pengujian Signifikansi Parameter Model Regresi Logistik Multivariat untuk kejadian Anemia

\begin{tabular}{lccc}
\hline \multicolumn{1}{c}{ Variabel } & OR & $95 \%$ & Sig \\
\hline Umur & & & \\
$20-35$ tahun & Ref & & 0,002 \\
$\quad<20$ tahun & 2,250 & $0,304-16,632$ & 0,427 \\
$\quad>35$ tahun & 5,885 & $2,180-15,882$ & 0,000 \\
\hline $\begin{array}{l}\text { Pendidikan } \\
\quad \text { Tinggi }\end{array}$ & Ref & & 0,762 \\
$\quad$ Menengah & 2,000 & $0,191-20,898$ & 0,563 \\
$\quad$ Dasar & 0,902 & $0,305-2,672$ & 0,852 \\
\hline Status Bekerja & & & 0,011 \\
$\quad$ Bekerja & Ref & & 0,065 \\
$\quad$ Tidak Bekerja & 1,990 & $0,959-4,127$ & \\
\hline Gravida & & & 0,116 \\
$\quad$ Primigravida & Ref & & 0,038 \\
$\quad$ Multigravida & 6,588 & $1,109-39,147$ & 0,053 \\
$\quad$ Grandemultigravida & 5,789 & $0,981-34,184$ & \\
\hline
\end{tabular}

Menurut Departemen Gizi dan Kesmas FKM UI (2007) Kehamilan yang terlalu sering dapat menyebabkan gizi kurang karena dapat menguras cadangan zat gizi tubuh serta organ reproduksi belum kembali sempurna seperti sebelum masa kehamilan ${ }^{10}$. Hal ini juga bisa disebabkan semakin banyak ibu mengalami kehamilan, maka ibu akan menjadi kurang perhatian kepada kehamilannya karena dianggap hal yang biasa dan sudah pernah mengalami, sehingga ibu yang semakin sering mengalami kehamilan tidak terlalu memperhatikan kesehatannya dibandingkan dengan kehamilan awal.

Dari tabel 4 dapat diketahui faktor umur ibu hamil yaitu 20-35 tahun dan >35 tahun, faktor status bekerja ibu hamil, dan ibu multigravida memiliki pengaruh signifikan terhadap kejadian Anemia pada ibu hamil. 
Dari faktor umur ibu hamil dapat diketahui bahwa ibu hamil yang berumur $<20$ tahun memiliki resiko mengalami Anemia 2,250 kali lebih besar dibandingkan dengan umur 20-35 tahun, dan usia > 35 tahun memiliki resiko mengalami Anemia 5,885 kali lebih besar dibandingkan dengan usia 20-35 tahun.

Hasil ini sejalan dengan hasil penelitian Nina (2006) yang mengatakan bahwa ada pengaruh umur ibu hamil dengan kejadian Anemia ${ }^{11}$. Dalam reproduksi sehat dikenal bahwa usia kehamilan yang aman untuk kehamilan dan persalinan adalah 21-35 tahun. Kehamilan pada usia muda lebih beresiko dibandingkan dengan usia dalam reproduksi sehat, angka kesakitan dan angka kematian ibu dan bayi pada kehamilan remaja dua hingga empat kali lebih tinggi dibandingkan dengan kehamilan di usia 20-35 tahun $^{12}$. Pada penelitian yang dilakukan di Southeast Ethiopia prevalensi Anemia lebih tinggi $(34,6 \%)$ pada wanita hamil dalam kelompok usia 18- 26 tahun hal ini membuktikan bahwa usia juga dapat menjadi faktor resiko ${ }^{13}$.

Kehamilan pada usia muda dapat menyebabkan terjadiya kompetisi makanan antar janin dan ibunya yang masih dalam pertumbuhan dan adanya pertumbuhan hormonal yang terjadi selama kehamilan. Sedangkan ibu hamil diatas 35 tahun cenderung mengalami Anemia, hal ini disebabkan adanya pengaruh turunnya cadangan zat besi dalam tubuh akibat masa fertilisasi ${ }^{7}$.

Dari faktor bekerja ibu hamil dapat diketahui bahwa ibu yang tidak bekerja memiliki resiko mengalami Anemia 1,990 lebih besar dibandingkan dengan ibu hamil yang bekerja. Hal ini bisa disebabkan karena ibu hamil yang tidak bekerja cenderung memiliki status sosial ekonomi yang lebih rendah dan mereka harus melakukan kerja keras selama kehamilan untuk mencukupi kebutuhannya. Sehingga kebutuhan nutrisi tidak tercukupi, jarak kelahiran pendek, perawatan antenatal yang tidak memadai ${ }^{14}$.

Ibu hamil dengan status pekerjaan tidak bekerja hanya sebagai ibu rumah tangga merupakan faktor resiko terjadinya Anemia karena sebagian besar pendapatannya bergantung pada penghasilan suami untuk memenuhi kebutuhannya, sebagian ibu rumah tangga tersebut merupakan pada tingkat sosial ekonomi rendah. Anemia ditemukan pada pendapatan bulanannya rendah ${ }^{3}$.

Dari faktor gravida diketahui bahwa ibu multigravida memiliki resiko mengalami Anemia 6,588 kali lebih besar dibandingkan ibu primigravida, dan ibu grandemultigravida juga memiliki resiko mengalami Anemia 5,789 lebih besar dibandingkan ibu primigravida. Hal ini sejalan dengan hasil penelitian Novita (2010) yang mengatakan bahwa ada hubungan jumlah kehamilan dengan kejadian Anemia ${ }^{15}$.

Sesuai dengan teori yang dikemukakan oleh Manuaba (2010) yang mengatakan bahwa Anemia dipengaruhi oleh kehamilan dan persalinan yang sering, semakin sering seorang wanita mengalami kehamilan dan persalinan akan semakin banyak kehilangan zat besi dan semakin anemis $^{16}$. Paritas mempengaruhi kejadian Anemia pada kehamilan, semakin sering seorang wanita hamil dan melahirkan maka risiko mengalami Anemia semakin besar karena kehamilan menguras cadangan zat besi dalam tubuh ${ }^{17}$.

\section{KESIMPULAN}

Kesimpulan dari penelitian adalah terdapat pengaruh status bekerja dan gravida ibu hamil (primigravida) terhadap kejadian KEK pada ibu hamil. Untuk kejadian anemia, didapatkan hasil bahwa tidak terdapat pengaruh tingkat pendidikan dengan kejadian anemia. Sebaliknya terdapat pengaruh umur (20-35 tahun dan > 35 tahun), status bekerja, gravida (ibu multigravida dan grandemultigravida) dengan kejadian anemia pada ibu hamil. Saran untuk ibu hamil adalah untuk melakukan konseling kepada petugas kesehatan secara teratur dan memenuhi kebutuhan nutrisinya selama hamil sesuai saran petugas kesehatan untuk mencegah terjadinya KEK dan anemia pada masa kehamilan. 


\section{ACKNOWLEDGEMENT}

Penghargaan diberikan penulis kepada seluruh staf pengajar Fakultas Kesehatan Masyarakat Universitas Airlangga atas bimbingan dan dukungan yang telah diberikan.

\section{REFERENSI}

1. Badan Penelitian dan Pengembangan Kesehatan Kementerian Kesehatan RI. (2013). Riset Kesehatan Dasar 2013. Diakses dari : www.depkes.go.id/resources/download/ general/Hasil\%20Riskesdas\%202013.pdf.

2. Achadi, E. L. (2007). Gizi dan kesehatan masyarakat. Depok : Rajawali Pers.

3. Obay, Ondogo, \& Wanyama. (2016). Prevalence of Anemia and associated risk factors among pregnant women attending antenatal care in gulu and hoima regional hospital in Uganda. BioMed Central Pregnancy and Childbirth. 2016; 16:76. DOI 10.1186/s12884-0160865-

4. Rukiyah, Ai Yeyeh, \& Lia Yulianti. (2010). Asuhan Kebidanan IV (Patologi Kebidanan). Jakarta: Trans Info Media.

5. Depkes RI. (2009). Sistem Kesehatan Nasional. Diakses dari : https://depkes.go.id

6. Darlina, Hardiansyah.(2003). Faktor resiko anemia pada ibu hamil di kota Bogor. Jurnal Media Gizi dan Keluarga.Vol.2 No.1. 3 - 41.

7. Setiawan, Murdianto. (2010). Hubungan Tingkat Konsumsi Dengan Anemia Dan Kek Pada Ibu Hamil Di Puskesmas Wonoayu Kabupaten Sidoarjo. (Skripsi, Universitas Airlangga, Surabaya). Diakses dari : repository.unair.ac.id/22070/

8. Sandjaja, A. (2009). Kamus Gizi : Pelengkap Kesehatan Keluarga. Jakarta: PT Gramedia Pustaka Utama.
9. Yuliastuti, (2014). Faktor-Faktor Yang Berhubungan Dengan Kekurangan Energi Kronis Pada Ibu Hamil Di Wilayah Kerja Puskesmas Sungai Bilu Banjarmasin. An Nadaa, Vol 1 No.2, Desember 2014, Hal 72-76 Issn 2442-4986

10. Departemen Gizi dan Kesmas FKM UI. (2007). Gizi dan kesehatan masyarakat edisi I. Jakarta: PT raja Grafindo Pesada.

11. Herlina N, Djamilus F. (2006). Faktor resiko kejadian Anemia pada ibu hamil di wilayah kerja Puskesmas Bogor. (Skripsi, IPB, Bogor). Diakses dari : repository.ipb.ac.id/.../faktor\%20resiko\% 20anemia\%20pada\%20ib.

12. Herlina, Nina. (2006). Faktor-faktor Resiko Kejadian Anemia pada Ibu Hamil. diakses dari: http://www.bppsdmk.depkes.go.id.

13. Iis Sinsin. (2008). Seri Kesehatan Ibu dan Anak Masa Kehamilan dan Persalinan. Jakarta: Alex Media.

14. Destaria, Selvi, Pramono, B Adi. (2011). Perbandingan luaran maternal dan perinatal kehamilan trimester ketiga antara usia muda dan usia reproduksi sehat. Universitas Diponogoro. Diakses dari

eprints.undip.ac.id/37290/1/Selvi_Destari a.pdf

15. Adelina, Novita. (2009). Status gizi bayi usia 1,5-8 bulan di jakarta selatan dan faktor-faktor yang berhubungan. (Skripsi. Universitas Indonesia, Jakarta). Diakses dari ib.ui.ac.id/file?file=digital/122811S09035fk-Status\%20gizi-HA.

16. Manuaba,IBG. (2010). Ilmu Kebidanan, penyakit Kandungan dan KB untuk Pendidikan Bidan Edisi 2. Jakarta: EGC.

17. Setya, dkk, (2012). Hubungan Tingkat Pengetahuan dan Sosial Ekonomi dengan Kejadian Anemia Pada Ibu hamil di Puskesmas Kabupaten Sidoarjo. (Skripsi, Universitas Brawijaya, Malang). Diakses dari : repository.ub.ac.id/26360/ 